\title{
EFFECT OF SOMATIC CELL COUNT ON MILK COMPOSITION AND MOZZARELLA CHEESE QUALITY
}

\author{
Y. HACHANA ${ }^{a *}$, A. ZNAIDI ${ }^{a}$ and N. M'HAMDI ${ }^{b}$ \\ ${ }^{a}$ Animal Sciences Department, Superior Institute of Agriculture, Chott-Meriam Susa, 4042 Susa. Tunisia \\ ${ }^{b}$ Laboratory of Animal Food and Genetic Resources, National Agronomic Institute of Tunisia, 1001 Cité \\ Mehrajane Tunis. Tunisia
}

(Received: 13 May 2017; accepted: 7 August 2017)

\begin{abstract}
The aim of this study was to investigate the effect of somatic cell count (SCC) on mozzarella cheese quality. Three categories of raw milk were selected: low ( $\mathrm{SCC}<115000$ cells $/ \mathrm{ml})$, medium $(\mathrm{SCC}=422000 \mathrm{cells} / \mathrm{ml})$, and high (SCC $>987000$ cells $/ \mathrm{ml})$. Cheeses were produced on the same day of milk collection and were vacuum packed in plastic bags and analysed weekly for 60 days at cold storage $\left(4^{\circ} \mathrm{C}\right)$. As somatic cell count increases, casein content, casein as a percentage of true protein, lactose content, and titratable acidity decrease significantly in raw milk. No significant differences were observed in moisture, fat, and total protein contents among mozzarella cheese samples from the different SCC categories. However, cheese samples produced from high SCC milk had significantly higher $\mathrm{pH}$ (6.83) compared to samples produced with low and medium SCC milk, 5.58 and 5.46, respectively. The extension of proteolysis was not significant for cheese samples made from raw milk with low SCC during the first 30 days of cold storage. Proteolysis levels increased significantly on the $15^{\text {th }}$ storage day for cheeses made with medium and high SCC, whereas significant increases were only observed on the $45^{\text {th }}$ storage day for cheeses made with low SCC.

Keywords: raw milk quality, somatic cell count, mozzarella cheese, proteolysis
\end{abstract}

Somatic cells are animal cells, which are naturally found in the milk. These cells include epithelial cells from the gland and leukocytes from the blood. Somatic cells in milk are mostly white blood cells that infiltrate the mammary gland in response to infection. When present in milk, they serve as a sensitive indicator of inflammatory conditions (Li et al., 2014). Mastitis is responsible for increasing the levels of somatic cells in milk. Most healthy cows in a dairy herd have a milk SCC less than 50000 cells/ml (BARBANO et al., 2006). When SCC exceed 200000 cells $/ \mathrm{ml}$, the udder is considered to be infected and mastitis is considered as subclinical (Li et al., 2014). Cows with subclinical mastitis show no differences in the appearance of their milk, but the composition and milk quality are altered because of the inflammation (DroR et al., 2015). Some studies have shown that an increase in SCC leads to a modification in milk composition. UBALDO and co-workers (2015) reported that mastitis can affect the quality and enhance proteolysis and lipolysis in milk. Somatic cells are considered important sources of enzymes, in particular proteases and lipases (KeLLY \& MCSwEENEY 2003). It was reported that elevated rates of SCC result in both decreased protein concentration and casein content (WICKSTROM et al., 2009), whereas non-casein nitrogen and whey protein increased under such conditions (Auldist \& HubBle, 1998). High SCC milk had lower lactose and higher pH compared to low and medium SCC (Troende et al., 2016). The negative effects of high SCC in raw milk on the dairy industry include reduced shelf life of dairy products due to undesirable sensory attributes caused mainly by lipolytic and proteolytic

* To whom correspondence should be addressed.

Phone: +21698475103 ; e-mail: hachana@yahoo.fr 
enzymes (KITCHEN, 1981). BARBANO and co-workers (2006) reported that SCC affects the shelf life of fluid milk and also the yield efficiency in manufactured milk products such as cheese. Higher levels of proteolysis have been observed in cheeses made with high SCC regardless the cheese type (LE MARÉCHAL et al., 2011). SCC results in decreased cheese yield as a consequence of the low casein content, which results in products of low quality and stability (COONEY et al., 2000). Cheeses made from milk with different levels of SCC had similar characteristics, but the extension and depth of proteolysis increased with SCC (UBALDo et al., 2015). High SCC milk induces an accelerated breakdown of $\alpha$ S1-casein. As a consequence, protein losses in the whey are increased (LE MARÉCHAL et al., 2011). The increase in SCC is also related to poor cheese manufacture, which impairs the cheese flavour, texture, and yield. CoELHO and co-workers (2014) reported that in order to get a good quality mozzarella cheese, it is necessary to use milk with somatic cell counts below 400000 cells $/ \mathrm{ml}$. According to the National Institute for Standardization and Industrial Property in Tunisia (NT-14-141-2004), the Tunisian standard for SCC states a threshold of 500000 cells/ml that should not be exceeded. In the USA, the legal maximum for SCC established by the Food and Drug Administration is 750000 cells $/ \mathrm{ml}$ for bovine milk. However, in the European Union Directive (EEC, 1992), the legal limit for bovine milk is 400000 cells $/ \mathrm{ml}$.

The aim of this study was to investigate the effects of three levels of somatic cells on raw milk composition and mozzarella cheese quality.

\section{Materials and methods}

\subsection{Milk selection}

Milk was obtained from different dairy farms, members of a local cooperative in the governorate of Monastir, Tunisia. On the basis of the SCC, raw milk samples were grouped into three categories: low SCC (115 000 cells/ml), medium SCC (422 000 cells/ml) and high SCC (987 000 cells $/ \mathrm{ml})$. Milk collected from the same group was bulked until a minimum amount of 100 litres was reached. Duplicate samples of bulked raw milk of each SCC category were analysed for confirmation of the final SCC. Milk was then cooled and stored at $4{ }^{\circ} \mathrm{C}$ until utilization ( $24 \mathrm{~h}$ after collection).

\subsection{Milk analysis}

All milk samples were tested negative for antibiotics using the Delvotest, and were analysed in duplicate for fat, total protein, lactose, and total solids by the Milkoscan 4000 (FossElectric A/C, Hillerod, Denmark) and for SCC (Fossomatic 5000, Foss-Electric A/C). Standards were provided by CECALAIT France to calibrate the equipment. Based on the data of the national milk control carried out monthly, the bacteriological counts of all milk

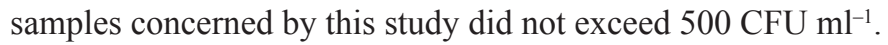

\subsection{Manufacture of mozzarella cheese}

The mozzarella was manufactured in a cheese factory located in the governorate of Monastir Tunisia, according to the procedure described by KINDSTEDT and co-workers (2004). During processing, aliquots of whey were collected in duplicate for the determination of fat, protein, total solids, titratable acidity, and $\mathrm{pH}$. One day after processing, 3 cheese samples from each category of SCC were taken and analysed in duplicate for moisture, fat, protein, total solids, 
titratable acidity, $\mathrm{pH}$, and proteolysis. Cheese samples were vacuum-packed in plastic bags and stored at $4{ }^{\circ} \mathrm{C}$ for up to 60 days. Physical and chemical analyses were performed in duplicate for cheese samples at 15 days interval $(1,15,30,45$, and 60 storage days) for moisture, fat, protein, titratable acidity, and $\mathrm{pH}$. The extension of proteolysis in cheese was calculated using total nitrogen (TN), $\mathrm{pH} 4$ 46-soluble nitrogen $(\mathrm{NCN})$, and $12 \%$ trichloroacetic acid soluble nitrogen (NPN).

\subsection{Statistical analyses}

Variance analysis was conducted for the repeated measures of the effects of SCC on raw milk and whey composition, as well as for the cheese composition of the 9 batches. The general linear model procedure SAS (SAS Institute, 2010) was used to this end. Significantly different means were identified using the Tukey's test. All statements of significance were based on $5 \%$ probability.

\section{Results and discussion}

\subsection{Effect of SCC on raw milk composition}

The low SCC milk used in the experiment (115 $000 \mathrm{cells} / \mathrm{ml}$ ) had a mean SCC value lower than $200000 \mathrm{cells} / \mathrm{ml}$ and was representative of healthy cows, whose cells originated from the natural scaling of the mammary gland epithelium (Fernandes et al., 2008). Milk with the highest SCC (987 000 cells $/ \mathrm{ml}$ ) largely exceeded the acceptable rate of SCC, as defined by the Tunisian National Institute for Standardization and Industrial Property (NT-14-141-2004) for bulked raw milk. Chemical composition, $\mathrm{pH}$, and acidity of raw milk with different levels of somatic cells count (SCC) are shown in Table 1. No significant effects of SCC have been recorded on fat content and total protein content of raw milk. However, as SCC increases, casein content and casein as percentage of true protein $(\mathrm{CN} / \mathrm{TP})$ decrease significantly $(\mathrm{P}<0.05)$ in raw milk (Table 1). These findings are in line with those of GEARY and co-workers (2013), who reported that as SCC increases, total nitrogen content of raw milk increases, casein as a percentage of true protein $(\mathrm{CN} / \mathrm{TP})$ decreases, whey protein increases, and the lactose content of raw milk decreases. There were no significant differences between raw milks with low and intermediate SCC for total solids, lactose content, $\mathrm{pH}$, and titratable acidity. However, significant differences of these parameters have been recorded for milk samples with low and high SCC (Table 1). This result is in line with the findings of GARIGLIA and co-workers (2015) as well as with those of TROENDLE and co-workers (2016), who reported that high SCC milk had lower lactose content and higher $\mathrm{pH}$ compared to low and medium SCC. ANDREATTA and co-workers (2009) found no significant differences between different classes of SCC except for lactose content. According to MACHADO and co-workers (2000), the reduced lactose content with high SCC is due to the decrease of lactose synthesis of the infected mammary glands. KoLTE and co-workers (2008) mentioned that permeability of the gland to blood components (such as bicarbonate ions) increased in infected udders, resulting in higher $\mathrm{pH}$ values of respective milk samples. 
Table 1. Effect of somatic cell count (SCC) on raw milk composition

\begin{tabular}{|c|c|c|c|c|c|c|}
\hline & \multicolumn{2}{|c|}{$\begin{array}{c}\text { Low SCC } \\
(115000 \text { cells } / \mathrm{ml})\end{array}$} & \multicolumn{2}{|c|}{$\begin{array}{l}\text { Intermediate SCC } \\
(422000 \text { cells } / \mathrm{ml})\end{array}$} & \multicolumn{2}{|c|}{$\begin{array}{c}\text { High SCC } \\
(987000 \text { cells/ml) }\end{array}$} \\
\hline & Mean & SD & Mean & SD & Mean & SD \\
\hline Fat $(\%)$ & 2.94 & 0.90 & 2.91 & 0.70 & 2.98 & 0.60 \\
\hline Total protein $(\%)$ & 2.90 & 0.30 & 3.01 & 0.40 & 2.95 & 0.30 \\
\hline Casein $(\%)$ & $2.31^{\mathrm{a}}$ & 0.20 & $1.98^{\mathrm{b}}$ & 0.60 & $1.88^{\mathrm{b}}$ & 0.40 \\
\hline Total solids $(\%)$ & $11.20^{\mathrm{b}}$ & 0.17 & $11.43^{\mathrm{ab}}$ & 0.20 & $12.28^{\mathrm{a}}$ & 0.19 \\
\hline $\mathrm{CN} / \mathrm{TP}$ & $79.66^{\mathrm{a}}$ & 1.25 & $65.78^{\mathrm{b}}$ & 0.98 & $63.73^{\mathrm{c}}$ & 1.33 \\
\hline Lactose $(\%)$ & $4.52^{\mathrm{a}}$ & 0.20 & $4.47^{\mathrm{ab}}$ & 0.10 & $4.21^{\mathrm{b}}$ & 0.20 \\
\hline $\mathrm{pH}$ & $6.73^{\mathrm{a}}$ & 0.06 & $6.71^{\mathrm{ab}}$ & 0.09 & $7.16^{\mathrm{b}}$ & 0.10 \\
\hline $\begin{array}{l}\text { Titratable acidity } \\
(\mathrm{g} \text { lactic acid/100 ml) }\end{array}$ & $0.15^{\mathrm{a}}$ & 0.02 & $0.15^{\mathrm{a}}$ & 0.01 & $0.13^{\mathrm{b}}$ & 0.04 \\
\hline
\end{tabular}

a, b, c: Means of duplicate analyses of three lots of each somatic cell counts category followed by different letters within a row are significantly different according to the Tukey's test at 5\% probability; SD: standard deviation; CN: casein; TP: true protein

\subsection{Effect of SCC on mozzarella composition}

The physico-chemical composition of mozzarella cheese made from milk samples with different levels of SCC content is presented in Table 2. Significant differences were only observed for $\mathrm{pH}$ and titratable acidity values $(\mathrm{P}<0.05)$. Cheese samples produced with high SCC milk had significantly higher $\mathrm{pH}$ and lower acidity compared to samples produced with low and medium SCC milk. In fact, mastitis causes damage to the mammary epithelium and leads to reduced synthesis and secretion of milk components. The amounts of blood borne components, such as serum albumin and sodium and chloride ions, increase in milk of infected quarters. This change in mineral balance causes the increase in $\mathrm{pH}$ in high SCC milk. Similar results were reported by VIANNA and co-workers (2008). MAZAL and co-workers (2007) revealed that during the manufacturing process, cheese from high SCC milk presents a mean $\mathrm{pH}$ value that was 0.25 units higher than the cheese resulting from low-SCC milk. Other authors, such as JAEGGI and co-workers (2003), did not observe significant variations of $\mathrm{pH}$ among cheeses made from milk samples having different SCC levels. MARINO and coworkers (2005), on adding somatic cells from mastitic milk to control milk, did not find significant differences of $\mathrm{pH}$ in cheeses. Results also show that there were no significant differences of other physico-chemical parameters analysed in this study (such as moisture, fat, and total protein contents), among the different mozzarella cheese samples manufactured from the different SCC milk samples. This is actually consistent with findings of UBALDO and co-workers (2015) and ANDREATTA and co-workers (2009), who used raw milk with high SCC (800 $000 \mathrm{cells} / \mathrm{ml}$ ) to produce mozzarella cheese. However, other studies carried out by MARINO and co-workers (2005) and VIANNA and co-workers (2008) on cheddar and cottage cheeses, reported significant $(\mathrm{P}<0.05)$ decrease in protein content with high SCC milk samples. 
Table 2. Effect of somatic cell count (SCC) on chemical composition of mozzarella cheese

\begin{tabular}{|c|c|c|c|c|c|c|}
\hline & \multicolumn{2}{|c|}{$\begin{array}{c}\text { Low SCC } \\
(115000 \text { cells } / \mathrm{ml})\end{array}$} & \multicolumn{2}{|c|}{$\begin{array}{l}\text { Intermediate } \mathrm{SCC} \\
(422000 \text { cells } / \mathrm{ml})\end{array}$} & \multicolumn{2}{|c|}{$\begin{array}{c}\text { High SCC } \\
(987000 \text { cells } / \mathrm{ml})\end{array}$} \\
\hline & Mean & $\mathrm{SD}$ & Mean & $\mathrm{SD}$ & Mean & SD \\
\hline Moisture (\%) & 48.76 & 1.91 & 48.81 & 0.82 & 47.59 & 1.20 \\
\hline Fat $(\%)$ & 25.51 & 2.52 & 25.68 & 1.98 & 25.56 & 3.08 \\
\hline Total protein $(\%)$ & 21.29 & 1.80 & 20.72 & 0.96 & 21.85 & 2.05 \\
\hline $\mathrm{pH}$ & $5.58^{\mathrm{b}}$ & 0.18 & $5.46^{\mathrm{b}}$ & 0.09 & $6.83^{\mathrm{a}}$ & 0.12 \\
\hline $\begin{array}{l}\text { Titratable acidity } \\
\text { (g lactic acid } / 100 \mathrm{ml})\end{array}$ & $0.57^{\mathrm{a}}$ & 0.14 & $0.53^{\mathrm{a}}$ & 0.20 & $0.31^{\mathrm{b}}$ & 0.08 \\
\hline
\end{tabular}

a, b: Means of duplicate analyses of three lots of each somatic cells counts category followed by different letters within a row are significantly different according to the Tukey’s test at 5\% probability; SD: standard deviation

\subsection{Effect of SCC on whey composition}

Results of whey components of the analysed cheese are indicated in Table 3. No significant differences $(\mathrm{P}>0.05)$ were observed among cheese whey compositions of the different SCC categories, except for $\mathrm{pH}$ and titratable acidity. SCC did not affect total solids, fat, and total protein contents in the cheese whey. However, significant increase $(\mathrm{P}<0.05)$ of the $\mathrm{pH}$ and decrease of the titratable acidity were noticed for the high SCC milk samples. This is consistent with the $\mathrm{pH}$ and acidity values observed in the respective raw milks. Similar results were reported by UBALDO and co-workers (2015). Conversely, other authors have also demonstrated increased protein levels in whey from high SCC milk (SiLva et al., 2012).

Table 3. Effect of somatic cell count (SCC) on cheese whey composition

\begin{tabular}{|c|c|c|c|c|c|c|}
\hline & \multicolumn{2}{|c|}{$\begin{array}{c}\text { Low SCC } \\
(115000 \text { cells } / \mathrm{ml})\end{array}$} & \multicolumn{2}{|c|}{$\begin{array}{l}\text { Intermediate SCC } \\
(422000 \text { cells } / \mathrm{ml})\end{array}$} & \multicolumn{2}{|c|}{$\begin{array}{c}\text { High SCC } \\
\text { (987000 cells/ml) }\end{array}$} \\
\hline & Mean & SD & Mean & SD & Mean & SD \\
\hline Total solids (\%) & 6.58 & 0.19 & 6.62 & 0.41 & 6.78 & 0.26 \\
\hline Fat $(\%)$ & 0.41 & 0.19 & 0.38 & 0.10 & 0.43 & 0.12 \\
\hline Total protein $(\%)$ & 0.81 & 0.06 & 0.79 & 0.04 & 0.87 & 0.08 \\
\hline $\mathrm{pH}$ & $6.58^{\mathrm{b}}$ & 0.19 & $6.62^{\mathrm{b}}$ & 0.14 & $7.02^{\mathrm{a}}$ & 0.24 \\
\hline $\begin{array}{l}\text { Titratable acidity } \\
\text { (g lactic acid/100 ml) }\end{array}$ & $0.08^{\mathrm{a}}$ & 0.01 & $0.09^{\mathrm{a}}$ & 0.01 & $0.05^{\mathrm{b}}$ & 0.01 \\
\hline
\end{tabular}

a, b: Means of duplicate analyses of three lots of each somatic cells counts category followed by different letters within a row are significantly different according to the Tukey's test at 5\% probability; SD: standard deviation

\subsection{Effect of SCC on extension of proteolysis}

Influence of storage at $4{ }^{\circ} \mathrm{C}$ on protein content of mozzarella cheese made from milk samples with different somatic cell counts is indicated in Table 4. 
Table 4. Influence of cold storage $\left(4^{\circ} \mathrm{C}\right)$ on total protein content of mozzarella made with different categories of somatic cell counts milks

\begin{tabular}{|c|c|c|c|c|c|c|c|c|c|c|}
\hline \multirow{3}{*}{$\begin{array}{l}\text { Total protein } \\
(\%)\end{array}$} & \multicolumn{10}{|c|}{ Storage time (day) } \\
\hline & \multicolumn{2}{|c|}{1} & \multicolumn{2}{|c|}{15} & \multicolumn{2}{|c|}{30} & \multicolumn{2}{|c|}{45} & \multicolumn{2}{|c|}{60} \\
\hline & Mean & $\mathrm{SD}$ & Mean & $\mathrm{SD}$ & Mean & SD & Mean & $\mathrm{SD}$ & Mean & SD \\
\hline Low SCC & 21.70 & 1.02 & 21.60 & 1.22 & 21.30 & 2.12 & 21.80 & 0.91 & 22.01 & 1.18 \\
\hline $\begin{array}{l}\text { Intermediate } \\
\text { SCC }\end{array}$ & 20.72 & 1.31 & 20.68 & 1.09 & 20.73 & 1.08 & 21.00 & 1.41 & 20.86 & 0.61 \\
\hline High SCC & 21.85 & 0.48 & 21.98 & 1.78 & 22.08 & 1.95 & 21.17 & 1.01 & 22.04 & 0.42 \\
\hline
\end{tabular}

Means of duplicate analyses of three lots of each somatic cells counts category; SD: standard deviation

Somatic cell count did not affect the total protein content of the mozzarella cheese during the cold storage period $\left(4^{\circ} \mathrm{C}\right)$. The extension of proteolysis in the mozzarella cheese throughout storage is indicated in Figure 1. Significant difference $(\mathrm{P}<0.05)$ was observed for proteolysis levels throughout storage. At the first day of storage, the extent of proteolysis of low SCC mozzarella cheese was about $1.38 \%$, while for intermediate and high SCC, proteolysis was about 4.56 and $6.65 \%$, respectively (Fig. 1).

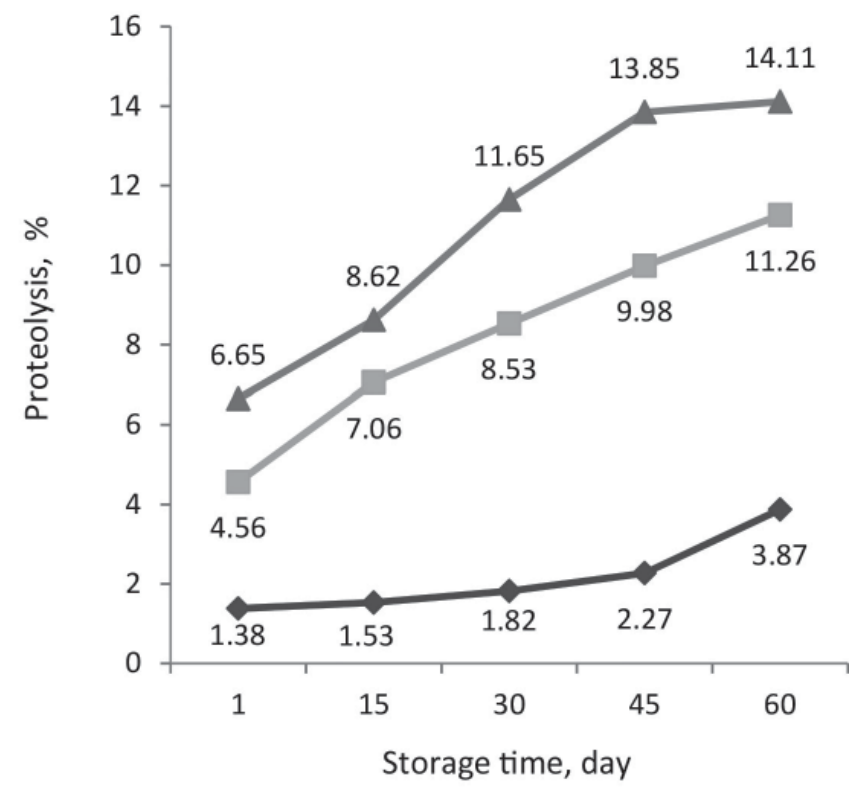

Fig. 1. Extension of proteolysis of mozzarella made with different categories of somatic cell counts milks during cold storage

Low SCC; -- : medium SCC, $\longrightarrow-$ : high SCC 
The extension of proteolysis was not significant $(\mathrm{P}>0.05)$ for cheese samples made from raw milk with low SCC during the first 30 days of cold storage. Proteolysis levels increased significantly $(\mathrm{P}<0.05)$ on the $15^{\text {th }}$ storage day for cheeses made with medium and high SCC. Significant increases of proteolysis levels were also observed at the $45^{\text {th }}$ storage day for cheeses made with low SCC, where it reached $2.27 \%$. The extension of proteolysis was highly remarkable for cheeses made from medium and high SCC raw milk. For the intermediate SCC milk content, the extension of proteolysis was about $4.56 \%$ on the first day of storage at $4{ }^{\circ} \mathrm{C}$, and reached $11.26 \%$ after 60 days of storage. For high SCC milk content, proteolysis was about $6.65 \%$ after 1 day of cold storage and $14.11 \%$ after 60 days of storage. These results clearly show that the use of high SCC milk leads to low protein quality mozzarella cheese, which might develop intense proteolysis during cold storage. In most rennet curd cheese varieties, proteolysis plays a major role in the development of flavour. However, for mozzarella cheese, which belongs to the category of stretched curd, or "pasta filata" cheeses, proteolysis is a major determinant of the intact casein content, which has a large impact on the quality of mozzarella. Levels of intact casein have been suggested as a significant determinant of stretching properties of melted mozzarella cheese (BANVILLE et al., 2013). The release of amino groups as a consequence of proteolysis in cheeses made with high SCC milk has been reported as a requisite to ensure browning via the Maillard reaction when the cheese is heated, regardless of the amount of residual sugars present in the cheese (KindSTEDT et al., 2004). UBALDO and co-workers (2015) reported a significant increase in proteolysis with increased SCC of the raw milk used in cheese production, and that the extension and depth of proteolysis varied from $1.43 \%$ to $6.85 \%$ and from $0.29 \%$ to $4.11 \%$, respectively. ANDREATTA and co-workers (2009) observed a significant increase $(\mathrm{P}<0.05)$ in free oil release during the storage of mozzarella cheese made with high SCC, and mentioned that the amount of free oil released from mozzarella depended on the proteolysis level during the storage. KALIT and co-workers (2002) observed a more intense proteolysis during ripening in the cheese from milk with a high SCC content. MAZAL and co-workers (2007) mentioned that the pH 4.6 SN was significantly higher in cheeses from high SCC milk, indicating intensive proteolysis in fresh cheese from high SCC milk after 5 days from the manufacturing date. Considine and co-workers (2002) mentioned that proteinases from somatic cells may potentially make a significant contribution to proteolysis in milk with high SCC or cheese made from such milk. JANA and MANDAL (2011) reported that the increased proteolysis in mozzarella cheese affects the integrity of the casein, which plays an important role in the stretch-ability characteristic, highly desired in the mozzarella cheese. ANDREATTA and coworkers (2009) showed that meltability increased in cheese manufactured from high SCC milk, and suggested that raw milk used to produce mozzarella cheese should not contain high SCC in order to avoid changes in the functional properties. In fact, plasminogen activator, which is synthetized by leucocytes in mastitic milk, is responsible for the formation of an endogenous milk protease, plasmin, which may be related to extensive caseinolysis (WANG et al., 2007).

\section{Conclusions}

Results of this study lead to the conclusion that somatic cell count did not affect fat content and total protein content of raw milk. However, casein content, casein as a percentage of true protein, titratable acidity, and lactose content decrease significantly in raw milk with increasing SCC content. Cheese samples produced with high SCC milk had significantly 
higher $\mathrm{pH}$ and lower acidity, compared to samples produced from milk with low and medium SCC content. No significant differences were observed on moisture, fat, and total protein contents among mozzarella cheese samples manufactured from the different SCC milk categories. Cheese whey composition was also not affected by the different SCC milk categories, except for $\mathrm{pH}$ and titratable acidity. During 60 days of cold storage, SCC did not affect the total protein content of the mozzarella cheese, but significantly influenced the development of proteolysis. As a conclusion, somatic cell count must be taken into consideration when selecting raw milk for the production of mozzarella cheese in order to avoid proteolysis and obtain high protein quality product. The SCC rate tolerated by the Tunisian standards can be considered as relatively high $(500000 \mathrm{cells} / \mathrm{ml})$ if the milk will be used to produce a mozzarella of excellent protein quality. Further studies are needed to determine the influence of SCC on the sensory acceptability of the final cheese product under the Tunisian conditions.

\section{References}

Andreatta, E., Fernandes, A.M., Santos, M.V., Mussarelli, C., Marques, M.C. \& Oliveira, C.A.F. (2009): Composition, functional properties and sensory characteristics of Mozzarella cheese manufactured from different somatic cell counts in milk. Braz. Arch. Biol. Techn., 52, 1235-1242.

Auldist, M.J. \& HubBle, I.B. (1998): Effects of mastitis on raw milk and dairy products. Aust. J. Dairy Technol., 53, 28-36.

Banville, V., Morin, P., Pouliot, Y. \& Britten, M. (2013): Physical properties of pizza Mozzarella cheese manufactured under different cheese-making conditions. J. Dairy Sci., 96, 4804-4815.

Barbano, D.M., MA, Y. \& Santos, M.V. (2006): Influence of raw milk quality on fluid milk shelf life. J. Dairy Sci., 89, 15-19.

Coelho, K.O., Mesquita, A.J., Rezende, C.S.M. \& Neves, R.B.S. (2014): Effect of somatic cells level to lactic culture used in the mozzarella cheese processing. 193-3., XII. Congresso Latino Americano de Microbiologia e Higiene de Alimentos. 12-15. October 2014, Iguacu, Paraná, Brazil

Considine, T., Geary, S., Kelly, A.L. \& McSweeney, P.L.H. (2002): Proteolytic specificity of cathepsin G on bovine $\alpha_{\mathrm{s} 1}$ - and $\beta$-caseins. Food Chem., 76, 59-67.

Cooney, S., Tiernan, D., Joyce, P. \& Kelly, A. (2000): Effect of somatic cell count and polymorphonuclear leucocyte content of milk on composition and proteolysis during ripening of Swiss-type-cheese. J. Dairy Res.. 67, 301-307.

Dror, B., Ludboy, L.K., Gil, K., Uzi, M. \& Gabriel, L. (2015): Influence of intramammary infection of a single gland in dairy cows on the cow's milk quality. J. Dairy Res., 82, 304-311.

EEC (1992): Council Directive 92/46/EEC of 16 June 1992 laying down the health rules for the production and placing on the market of raw milk, heat-treated milk and milk-based products.

Fernandes, A.M., Moretti, T.S., Bovo, F., Lima, C.G. \& Oliveira, C.A.F. (2008): Effect of somatic cell counts on lipolysis, proteolysis and apparent viscosity of UHT milk during storage. Int. J. Dairy Technol., 61, 327-332.

Gariglia, B.A.D., Santos, P.A., Araujo, L.S., Giovannini, C.I., Neves, R.B.S., Nicolo, E.S. \& DA Silva, M.A.P. (2015): Effect of the somatic cell count on physicochemical components of milk from crossbred cows. Afr. J. Biotechnol., 14, 1519-1524.

Geary, U., Lopez-Villalobos, N., O’Brien, B., Garrick, D.J. \& Shallool, L. (2013): Meta-analysis to investigate relationships between somatic cell count and raw milk composition. (Cheddar cheese processing characteristics and cheese composition) Irish J. Agr. Food Res., 52, 119-133.

JAeggi, J.J., Govindasamy-Lucey, S., Berger, Y.M. \& Johnson, M.E. (2003): Hard ewe's milk cheese manufactures from milk of three different groups of somatic cell counts. J. Dairy Sci., 86, 3082-3089.

JANA, A.H. \& Mandal, P.K. (2011): Manufacturing and quality of Mozzarella cheese: A review. Int. J. Dairy Sci., 6, 199-226.

Kalit, S., Havranek, J.L. \& Kaps, M. (2002): Plasminogen activation and somatic cell count in cheese milk (Influence on Podravec cheese ripening). Milchwissenschaft, 57, 380-382. 
Kelly, A.L. \& McSweeney, P.L.H. (2003): Indigenous proteolytic enzymes in milk. -in: Fox, P.F. \& McSweEney, P.L.H (Eds) Advanced dairy chemistry. Vol.IA Proteins Kluwer Academic Plenum Publishers, New York, NY, USA. pp. 495-544.

Kindstedt, P., Carlic, M. \& Milanovic, S. (2004): Pasta-filata cheeses. -in: Fox, P.F., McSweeney, P.L.H., Cogan, T.M. \& GuineE, T.P. (2004) Cheese: Chemistry, physics and microbiology. Elsevier: Academic Press. London UK. pp. 251-277.

Kitchen, B.J. (1981): Review of the progress of dairy science: bovine mastitis: milk compositional changes and related diagnostic tests. J. Dairy Res., 48, 167-188.

Kolte, A.Y., Waghmare, S.P., Mode, S.G. \& Handa, A. (2008): Efficacy of indigenous herbal preparation on altered milk pH, somatic cell count and electrolyte profile in subclinical mastitis in cows. Vet. World, 1, 239-240.

Le Maréchal, C., Thiéry, R., Vautor, E. \& Le Loir, Y. (2011): Mastitis impact on technological properties of milk and quality of milk products - a review. Dairy Sci. Technol., 91, 247-282.

Li, N., Richoux, R., Boutinaud, M., Martin, P. \& Gagnaire, V. (2014): Role of somatic cells on dairy processes and products (a review). Dairy Sci. Technol., 94, 517-538.

Machado, P.F., Pereira, A.R. \& SArríes, G.A. (2000): Composição do leite de tanques de rebanhos brasileiros distribuídos egundo sua contagem de células somáticas. (Milk composition of Brazilian herds according to their somatic cell count.) Rev. Bras. Zootecn., 29, 1883-1886.

Marino, R., Considine, T., Sevi, A., McSweeney, P.L.H. \& Kelly, A.L. (2005): Contribution of proteolytic activity associated with somatic cells in milk to cheese ripening. Int. Dairy J., 15, 1026-1033.

Mazal, G., Vianna, P.C.B., Santos, M.V. \& Gigante, M.L. (2007): Effect of somatic cell count on Prato cheese composition. J. Dairy Sci., 90, 630-636.

Silva, N.M.A., Bastos, L.P.F., Oliveira, D.L.S., Oliveira, M.C.P. \& Fonseca, L.M. (2012): Influence of somatic cell count and total bacterial counts of raw milk in cheese yield using small-scale methodology. Arq. Bras. Med. Vet. Zoo., 64, 1367-1372.

Troendle, J.A., Tauer, L.W. \& GröHN†, T.G. (2016): Optimally achieving milk bulk tank somatic cell count thresholds. J. Dairy Sci., 100, 731-738.

Tunisian STANDARD (2004): Lait cru destiné à la transformation - spécifications. (Raw milk for processing specifications.) National Institute for Standardization and Industrial Property in Tunisia No. NT-14-141-2004

Ubaldo, J.C.S.R., Carvalho, A.F., Fonseca, L.M. \& Gloria, M.B.A. (2015): Bioactive amines in Mozzarella cheese from milk with varying somatic cell counts. Food Chem., 178, 229-235.

Vianna, C.P.B., Mazal, G., Santos, M.V., Bolini, H.M.A. \& Gigante, M.L. (2008): Microbial and sensory changes throughout the ripening of Prato cheese made from milk with different levels of somatic cells. J. Dairy Sci., 91, 1743-1750.

Wang, C., Liu, J.X., Yuan, Z.P., Wu, Y.M., ZhaI, S.W. \& Ye, H.W. (2007): Effect of level of metabolizable protein on milk production and nitrogen utilization in lactating dairy cows. J. Dairy Sci., 90, 2960-2965.

Wickstrom, E., Persson-Waller, K., Lindmark-Mansson, H., Ostensson, K. \& Sternesjo, A. (2009): Relationship between somatic cell count, polymorphonuclear leucocyte count and quality parameters in bovine bulk tank milk. J. Dairy Res., 76, 195-201. 